Original Article

\title{
H. SABDARIFFA CALYCES ASH: ANTIANXIETY AND ANTIDEPRESSANT ACTIVITY EVALUATION AND PREPARATION OF ITS TABLETS
}

\author{
GULSHEEN $^{1}$, ASHWANI KUMAR ${ }^{1 *}$, ANUPAM SHARMA ${ }^{1}$ \\ ${ }^{1}$ University Institute of Pharmaceutical Sciences, Panjab University, Chandigarh 160014, India \\ *Email: bashwani@pu.ac.in
}

Received: 17 Nov 2020, Revised and Accepted: 02 Feb 2021

\begin{abstract}
Objective: Ash and its preparations have been used in Ayurveda for the treatment of various ailments since $7^{\text {th }}$ century AD. Numerous studies suggest that the elements present in ash have significant role in affective disorders. Thus, the present study aimed at evaluating the antianxiety and antidepressant activity of total ash of $H$. sabdariffa calyces, and also of the tablets of total ash.
\end{abstract}

Methods: Powdered calyces were taken in tared silica crucible, and were incinerated at a temperature not exceeding $450{ }^{\circ} \mathrm{C}$. The resultant ash was cooled and weighed. This was evaluated for antianxiety and antidepressant activity using an elevated plus maze and Porsolt's swim test, respectively. Further, the ash samples were analysed through ICP-MS to know their composition. The ash was formulated into tablets using the wet granulation technique, using only organic excipients.

Results: Results indicated that the total ash of $H$. sabdariffa calyces exhibited significant $(\mathrm{p}<0.001)$ antianxiety and antidepressant activity at 50 and $100 \mathrm{mg} / \mathrm{kg}$, po, respectively. The activities were comparable to the standard drugs. ICP-MS analysis showed the presence of magnesium, phosphorous, potassium and calcium as major elements. Tablets of $H$. sabdariffa total ash were as effective (p<0.001) as the total ash.

Conclusion: Magnesium, phosphorous, potassium and calcium have been reported to play a significant role in affective disorders, explaining, thereby, as to why ash of $H$. sabdariffa calyces exhibited anti-anxiety and antidepressant activity.

Keywords: Total ash, Antianxiety, Antidepressant, Elevated plus maze, Porsolt's despair test, Tablets, ICP-MS, Elements

(C) 2021 The Authors. Published by Innovare Academic Sciences Pvt Ltd. This is an open access article under the CC BY license (https://creativecommons.org/licenses/by/4.0/] DOI: https://dx.doi.org/10.22159/ijpps.2021v13i4.40264. Journal homepage: https://innovareacademics.in/journals/index.php/ijpps.

\section{INTRODUCTION}

Affective disorders, especially anxiety and depression are among the most common psychiatric problems globally, with prevalence rates of $3.6 \%$ and $4.4 \%$, respectively [1]. Anxiety is a frequent negative emotional state, manifested as unsettling feeling of concern or worry that is displayed by worried facial expressions and bodily responses like muscle tension, restlessness, impaired concentration, sleep disturbances and irritability [2]. Depression is characterized by recurring episodes of dysphoria and negative thinking that is reflected in behaviour [3]. Over the years, relationship between anxiety and depression has been extensively examined, and studies show that anxiety often precedes depressive disorders. Reported percentage comorbidity for anxiety and depression is estimated to be $70 \%$ [4]. A wide range of therapeutic drugs are available for treatment of anxiety and depression, ranging from specific drugs like barbiturates, benzodiazepines to atypical drugs like buspiron as well as antipsychotics all of which exhibit various types of side effects [5]. Given the issues with current treatment options, patients are inclining towards complementary and alternative medicines (CAM), i.e., herbal remedies, meditation and spiritual practices, acupuncture and dietary practices; with more than $80 \%$ of the population worldwide relying on herbs for the treatment of specific disorders [6, 7].

Bhasmas/metallic preparations have been extensively employed in Ayurvedic and Unani systems of medicine for the treatment of various ailments. Bhasmas are essentially ashes obtained through incineration. Numerous literature reports have shown that essential elements present in bhasmas are involved in the neurobiological mechanisms of various diseases including anxiety and depression. Deficiencies of these essential elements are associated with the pathogenesis of anxiety and depression [8-10]. Thus, taking cue from the literature, the present study was designed to evaluate the antianxiety and antidepressant activity of total ash of $H$. sabdariffa calyces. Calyces of $H$. sabdariffa (Malvaceae), popularly known as Red Sorrel (English) or Lal Ambari (Hindi), have been used in folk medicine in the management of nervous disorders, and also as sedative, diuretic, diaphoretic, choleretic, laxative, antifungal, antibacterial and antitussive $[11,12]$. The authors have already reported that the ethanol extract of $H$. sabdariffa calyces exhibits significant antianxiety and antidepressant activity in mice [13].

\section{MATERIALS AND METHODS}

Plant material

Dried calyces of $H$. sabdariffa were procured from Earth Expo Company, Gujarat, India. These were authenticated by comparing their morphological and microscopical characters with those reported in the literature [14]. Voucher specimen (Number 252) of the calyces has been deposited in Herbarium-cum-Museum of University Institute of Pharmaceutical Sciences, Panjab University, Chandigarh.

\section{Preparation of ash and determination of ash values}

Powdered plant material (10 g) was taken in tared silica crucible, and incinerated in muffle furnace at a temperature not exceeding $450{ }^{\circ} \mathrm{C}$ until free from carbon. The resultant ash was cooled and weighed. Ash values (total, acid-insoluble and water-soluble) of the plant material were determined, in triplicate, following the procedures prescribed in USP [15].

\section{Experimental animals}

Lacca mice (either sex), housed at the Central Animal House, Panjab University, were allowed standard pellet diet (Ashirwad, Chandigarh) and water ad libitum. Groups of 6 mice (20-30 g) were used in all sets of experiments. The animals were fasted for $12 \mathrm{~h}$ before use. Approval (PU/IAEC/S/16/112) from the Institutional Animal Ethical Committee of Panjab University, Chandigarh was taken before carrying out biological studies. Standard group received diazepam (Jawa Pharmaceuticals Pvt. Ltd., Gurugram) or imipramine (Torrent Pharmaceuticals, Solan, India). 


\section{Dosing and treatment}

Tween $80(5 \%)$ in aqueous carboxymethylcellulose (CMC 0.5\% w/w) was used as a vehicle for preparing the suspension of total ash. Doses were prepared by suspending appropriate quantities in the vehicle so as to administer these to mice in volumes ranging between $0.20-0.30$ $\mathrm{ml}$ per oral route. Mice were randomly divided into control, test and standard drug groups, each comprising 6 animals. Control group was administered vehicle only. Test groups received the suspension of total ash or tablets of total ash of H. sabdariffa calyces.

\section{Acute toxicity studies of the total ash}

Acute toxicity studies of total ash of $\mathrm{H}$. sabdariffa calyces were carried out on mice as per OECD 423 guidelines [16]. After $12 \mathrm{~h}$ of fasting, different groups of mice were administered a single oral dose 500 , 1000 or $2000 \mathrm{mg} / \mathrm{kg}$ ) of the total ash. Immediately after dosing, animals were observed for signs of toxicity during the first $0.5,1,2,4$, 8 and $12 \mathrm{~h}$, and at every $24 \mathrm{~h}$ for $14 \mathrm{~d}$. Behavioral parameters, tremors, lethargy, death, amount of water and feed taken were observed.

\section{Antianxiety activity evaluation: elevated plus-maze model}

Antianxiety activity was evaluated using elevated plus maze (EPM) model $[17,18]$. The apparatus consisted of two open arms $(16 \times 5$ $\mathrm{cm})$ and two closed arms $(16 \times 5 \times 12 \mathrm{~cm})$ having an open roof. It was kept elevated $(25 \mathrm{~cm})$ from the floor for evaluating the anxiolytic behavior. Doses were administered orally using tuberculin syringe fitted with an oral cannula. The dose administration schedule was so adjusted that each mouse was having its turn on the EPM 60 min after the administration of the vehicle, diazepam or the test substance. Each mouse was placed at the centre of EPM with its head facing towards the open arm. During 5 min duration of the experiment, the behavior of the mouse was recorded as (a) the number of entries into the open arms and (b) mean time spent by the mouse in open arms. The arms of EPM were cleaned using ethanol-soaked cotton swab every time the animal was used for recording the results.

\section{Antidepresant activity evaluation: porsolt's forced swim test}

Forced swim test (FST) was used to evaluate antidepressant activity $[18,19]$. Mice were forced to swim in a vertical Plexiglas jar $(25 \times 12 \times 25 \mathrm{~cm})$ containing water upto a height of $15 \mathrm{~cm}$ at room temperature $\left(25 \pm 1^{\circ} \mathrm{C}\right)$. Mice were administered standard antidepressant imipramine or the test substance $60 \mathrm{~min}$ before the evaluation. After an initial period of vigorous activity to escape, the animals assumed a typical immobile posture (ceased to struggle with minimal limb movements just sufficient to keep their head above the level of water). Total immobility period during $6 \mathrm{~min}$ session was noted. Antianxiety and antidepressant activity evaluation of total ash
of $H$. sabdariffa calyces

The total ash of $H$. sabdariffa calyces was evaluated for antianxiety and antidepressant activity using EPM and FST, respectively at the dose of 25, 50, 100 and $200 \mathrm{mg} / \mathrm{kg}$, po.

\section{Preparation of tablets}

The total ash of H. sabdariffa calyces was formulated as tablets (50 $\mathrm{mg}$ ) using wet granulation technique. Ash of $H$. sabdariffa was mixed with lactose and dry starch in a polythene bag. This was followed by slow addition of $10 \%$ starch paste to form a uniform mass which was passed through sieve (\#16) and dried in hot air oven at a temperature not exceeding $50{ }^{\circ} \mathrm{C}$. Dried granules were mixed with stearic acid and passed through a sieve (\#20). The granules were compressed using direct compression tablet punching machine. Before compression, the dies and punches were lubricated with stearic acid. Three batches, each of hundred tablets, were prepared and stored in an airtight container at room temperature for further studies. Placebo was prepared in the similar manner. While preparing the tablets, it was ensured to use only organic excipients to prevent any elevation or diminution of activity due to the inorganic composition of the excipients. Both the placebo and $H$. sabdariffa total ash tablets were subjected to antianxiety and antidepressant activity evaluation using EPM and FST, respectively.

\section{Evaluation of Pre-formulation and Post-formulation parameters}

The tablet granules were subjected to pre-formulation parameters' evaluation (angle of repose, bulk density, tapped density, Hausner's ratio and Carr's index) prior to compression. The prepared tablets were subjected to post-formulation parameters' (visual inspection, hardness, friability, uniformity in weight and disintegration time). The ash content uniformity of the tablets was determined gravimetrically by incinerating 20 tablets as per the procedure for preparing the total ash. The content determination was performed in triplicate. Both pre and post-formulation parameters were evaluated following the procedures prescribed in USP, 2014 [15].

Antianxiety and antidepressant activity evaluation of tablets of total ash of $\boldsymbol{H}$. sabdariffa calyces

Placebo and $H$. sabdariffa total ash tablets were evaluated for antianxiety and antidepressant activity at dose of 50 and $100 \mathrm{mg} / \mathrm{kg}$, respectively.

\section{Elemental analysis of total-ash: ICP-MS technique}

The total-ash of $H$. sabdariffa calyces was analyzed for quantitative estimation of different elements using inductively coupled plasmamass spectrometer (Agilent 7900, IIT Delhi).

Antianxiety and antidepressant activity evaluation of major elements in total ash of $\boldsymbol{H}$. sabdariffa calyces

Salts of the major elements (Mg, K and Ca) present in the total ash of $H$. sabdariffa calyces were evaluated for antianxiety and antidepressant activity using EPM and FST, respectively. Doses of the salts $\left(\mathrm{MgSO}_{4}, \mathrm{~K}_{2} \mathrm{SO}_{4}\right.$ and $\left.\mathrm{CaCO}_{3}\right)$ were calculated according to the percentage concentration of each element present in the total ash.

\section{Statistical analysis}

The data have been expressed as mean \pm standard error of mean (SEM). Significant differences among the groups were assessed by one way analysis of variance (ANOVA) using GraphPad Prism 5. The test was followed by Tukey's multiple range test; $p$ values less than 0.001 were considered as significant.

\section{RESULTS}

Determination of ash values of $\boldsymbol{H}$. sabdariffa calyces

Table 1 shows the results of ash value determination of $H$. sabdariffa calyces.

Table 1: Ash values of the H. sabdariffa calyces

\begin{tabular}{ll}
\hline Ash & Ash values $^{*}(\mathbf{\%} \mathbf{~ w} / \mathbf{w})\left(\right.$ Mean $^{\#} \pm$ SEM) \\
\hline Total-ash & $7.19 \pm 0.008$ \\
Acid insoluble ash & $0.53 \pm 0.005$ \\
Water-soluble ash & $1.20 \pm 0.005$ \\
\hline
\end{tabular}

*dry weight basis, ${ }^{\mathrm{n}}=3$

\section{Acute toxicity studies}

No toxic effects were observed in the total-ash of $H$. sabdariffa calyces up to a dose of $2000 \mathrm{mg} / \mathrm{kg}$.

\section{Preparation of tablets}

Table 2 shows the formula for placebo and H. sabdariffa total ash tablets.

Table 2: Formula of placebo and $\boldsymbol{H}$. sabdariffa total ash tablets

\begin{tabular}{lll}
\hline Ingredients & \multicolumn{2}{l}{ Quantity per tablet (mg) } \\
\cline { 2 - 3 } & Placebo & H. sabdariffa total ash tablets \\
\hline Ash & - & 1 \\
Stearic acid & 2 & 2 \\
Lactose & 29 & 26 \\
Starch dry & 8 & 6 \\
Starch paste & q. s. & q. s \\
\hline
\end{tabular}

\section{Pre formulation and post formulation parameters' evaluation}

The results of pre and post formulation parameters' evaluation are depicted in table 3 and 4 , respectively. 
Ashwani et al.

Table 3: Results of pre-formulation parameters' evaluation

\begin{tabular}{lllll}
\hline S. No. & Parameter & Placebo & & \multicolumn{2}{l}{ H. sabdariffa total-ash tablets } \\
\cline { 3 - 5 } & & Observation & Inference & Observation \\
\hline 1. & Angle of repose & $25.26^{\circ}$ & Excellent & $25.52^{\circ}$ \\
2. & Bulk density & $0.47 \mathrm{~g} / \mathrm{ml}$ & - & $0.49 \mathrm{~g} / \mathrm{ml}$ \\
3. & Tapped density & $0.54 \mathrm{~g} / \mathrm{ml}$ & - & $0.56 \mathrm{~g} / \mathrm{ml}$ \\
4. & Hausner's ratio & 1.14 & Good & 1.14 \\
5. & Carr's index & $12.96 \%$ & Good & - \\
\hline
\end{tabular}

Table 4: Mean** ${ }^{* *}$ SEM values of post-formulation parameters' evaluation

\begin{tabular}{llll}
\hline S. No. & Evaluation parameter & Placebo & H. sabdariffa tablets \\
\hline 1. & Diameter & $5.08 \pm 0.005 \mathrm{~mm}$ & $5.06 \pm 0.005 \mathrm{~mm}$ \\
2. & Thickness & $2.17 \pm 0.005 \mathrm{~mm}$ & $2.20 \pm 0.005 \mathrm{~mm}$ \\
3. & Hardness & $5.60 \pm 0.005 \mathrm{~kg} / \mathrm{cm}^{2}$ & $6.04 \pm 0.005 \mathrm{~kg} / \mathrm{cm}^{2}$ \\
4. & Friability* & $0.17 \pm 0.005 \%$ & $0.19 \pm 0.005 \%$ \\
5. & \% weight variation ${ }^{\#}$ & $5.30 \pm 0.005 \%$ & $4.39 \pm 0.005 \%$ \\
6. & Disintegration time & $5.40 \pm 0.005 \mathrm{sec}$ & $35.00 \pm 0.005 \mathrm{sec}$ \\
7. & Drug Content Estimation ${ }^{\text {and }}$ & $0 \pm 0.00 \mathrm{mg}$ & $1 \pm 0.00 \mathrm{mg}$ \\
\hline
\end{tabular}

${ }^{* *} \mathrm{n}=3$, USP, 2014 prescribed limits. *: $\leq 1 \%$; \#: $\pm 10 \%$; $\$ \leq 15$ min; and: $\pm 10 \%$

Antianxiety and antidepressant activity evaluation of total ash and its tablets of $H$. sabdariffa calyces

Administration of diazepam ( $2 \mathrm{mg} / \mathrm{kg}$ ) significantly increased the number of entries and the time spent in the open arms compared to the control group. Both the total ash of $H$. sabdariffa calyces and its tablets thereof exhibited significant antianxiety activity at a dose of $50 \mathrm{mg} / \mathrm{kg}$ (fig. 1 and 2). Similarly, at a dose of $100 \mathrm{mg} / \mathrm{kg}$, these demonstrated a statistically significant diminution of immobility time when the animals were subjected to FST (fig. 3 and 4). Results of imipramine $(10 \mathrm{mg} / \mathrm{kg}$ ) were similar to results of those observed with the total ash.

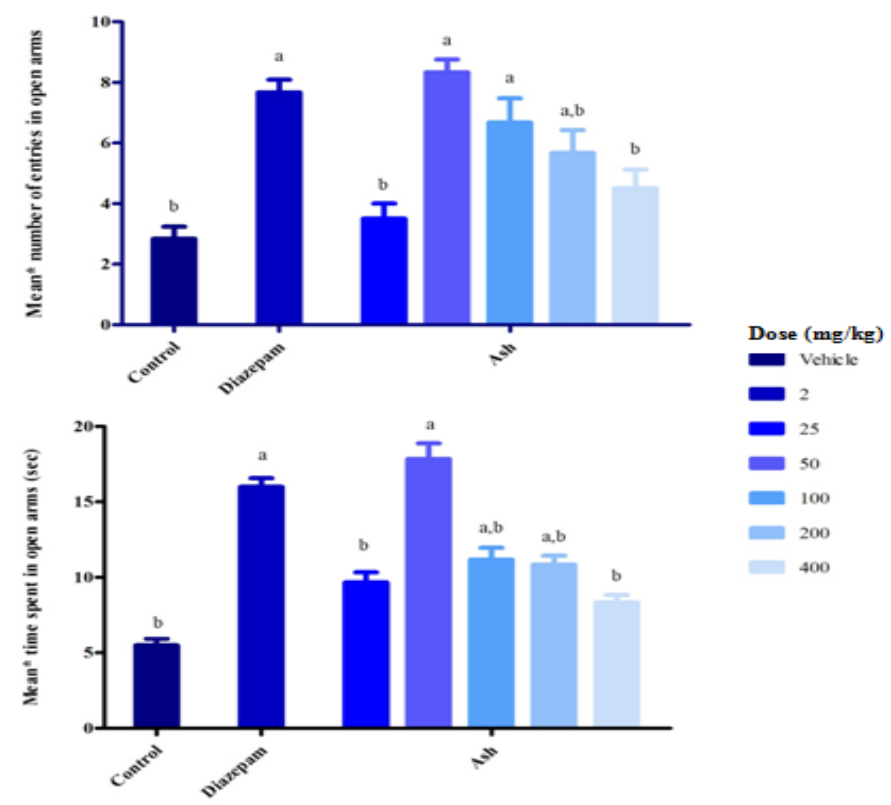

Fig. 1: Antianxiety activity profile of total-ash of $H$. sabdariffa calyces using EPM. The data is expressed as mean \pm SEM; ${ }^{*} n=6$; ${ }^{a}<<0.001$ vs control; b ${ }^{2}<0.001 v s$ diazepam; one way ANOVA followed by Tukey's multiple range tests

Table 5: Results of quantitative estimation of elements present in total ash of $\boldsymbol{H}$. sabdariffa calyces by ICP-MS technique

\begin{tabular}{llll}
\hline Element & \% Concentration & Element & \% Concentration \\
\hline $\mathrm{Ag}$ & 0.000004 & $\mathrm{Mg}$ & 0.316655 \\
$\mathrm{Al}$ & 0.029504 & $\mathrm{Mn}$ & 0.029390 \\
$\mathrm{As}$ & 0.000010 & $\mathrm{Ni}$ & 0.000339 \\
$\mathrm{Au}$ & 0.000001 & $\mathrm{P}$ & 0.020696 \\
$\mathrm{Ca}$ & 0.297205 & $\mathrm{~Pb}$ & 0.000061 \\
$\mathrm{Cd}$ & $\mathrm{Pt}$ & 0.000000 \\
$\mathrm{Co}$ & 0.000009 & $\mathrm{Se}$ & 0.000016 \\
$\mathrm{Cu}$ & 0.000037 & $\mathrm{Sn}$ & 0.000046 \\
$\mathrm{Fe}$ & 0.001341 & $\mathrm{Zn}$ & 0.004037 \\
$\mathrm{~K}$ & 0.029330 & - & - \\
\hline
\end{tabular}



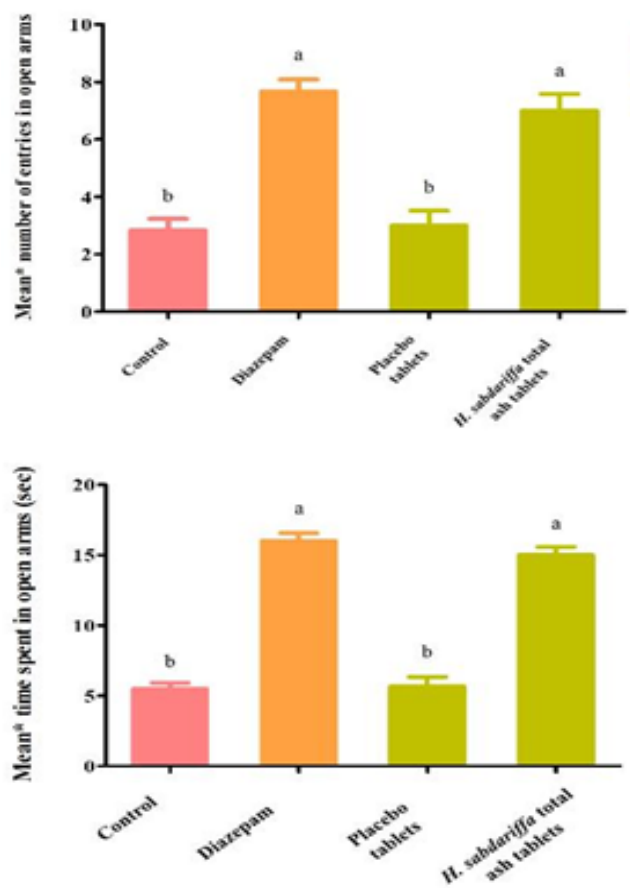

Dose (mg/kg)

Vehicle

2

50

Fig. 2: Antianxiety activity profile of Placebo and $H$. sabdariffa total ash tablets using EPM. The data is expressed as mean \pm SEM; *n=6; ${ }^{a} \mathbf{p}<0.001$ vs diazepam; b $<0.001$ vs control; one way ANOVA followed by Tukey's multiple range test

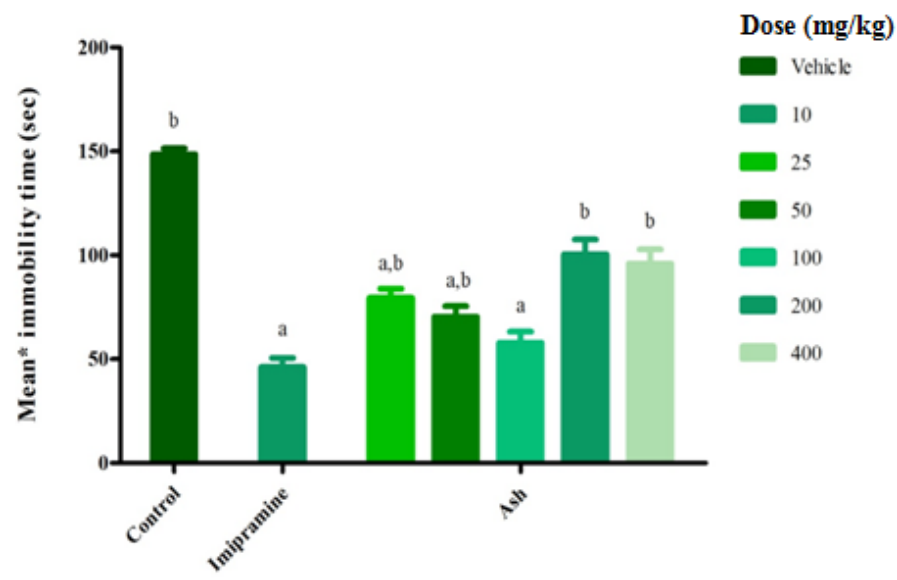

Fig. 3: Antidepressant activity profile of total ash of $H$. sabdariffa calyces using FST. The data is expressed as mean \pm SEM; ${ }^{*}=6$; ap $<0.001$ vs control; ${ }^{b} \mathbf{p}<0.001$ vs imipramine; one way ANOVA followed by Tukey's multiple range test

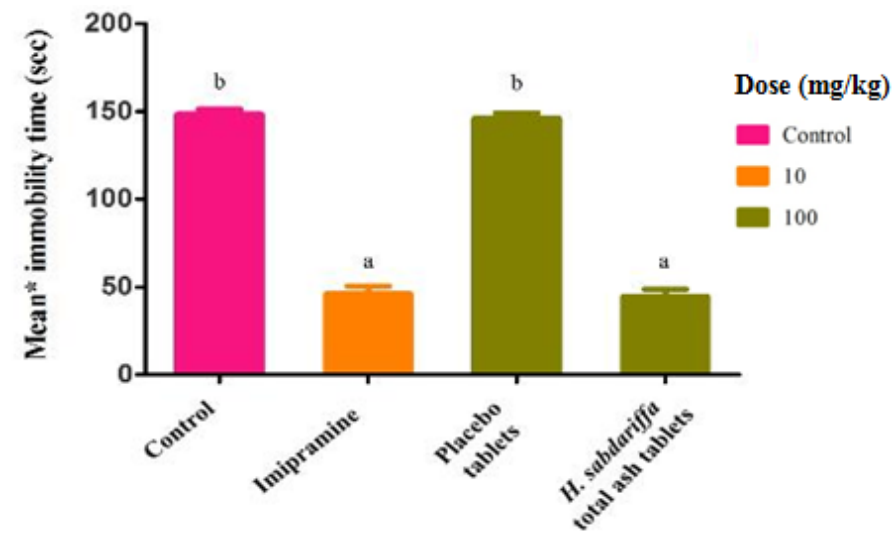

Fig. 4: Antidepressant activity profile of placebo and $H$. sabdariffa total ash tablet using FST. The data is expressed as mean \pm SEM; *n=6; ${ }^{a} \mathrm{p}<0.001$ vs imipramine; b $<0.001 v s$ control; one way ANOVA followed by Tukey's multiple range test 


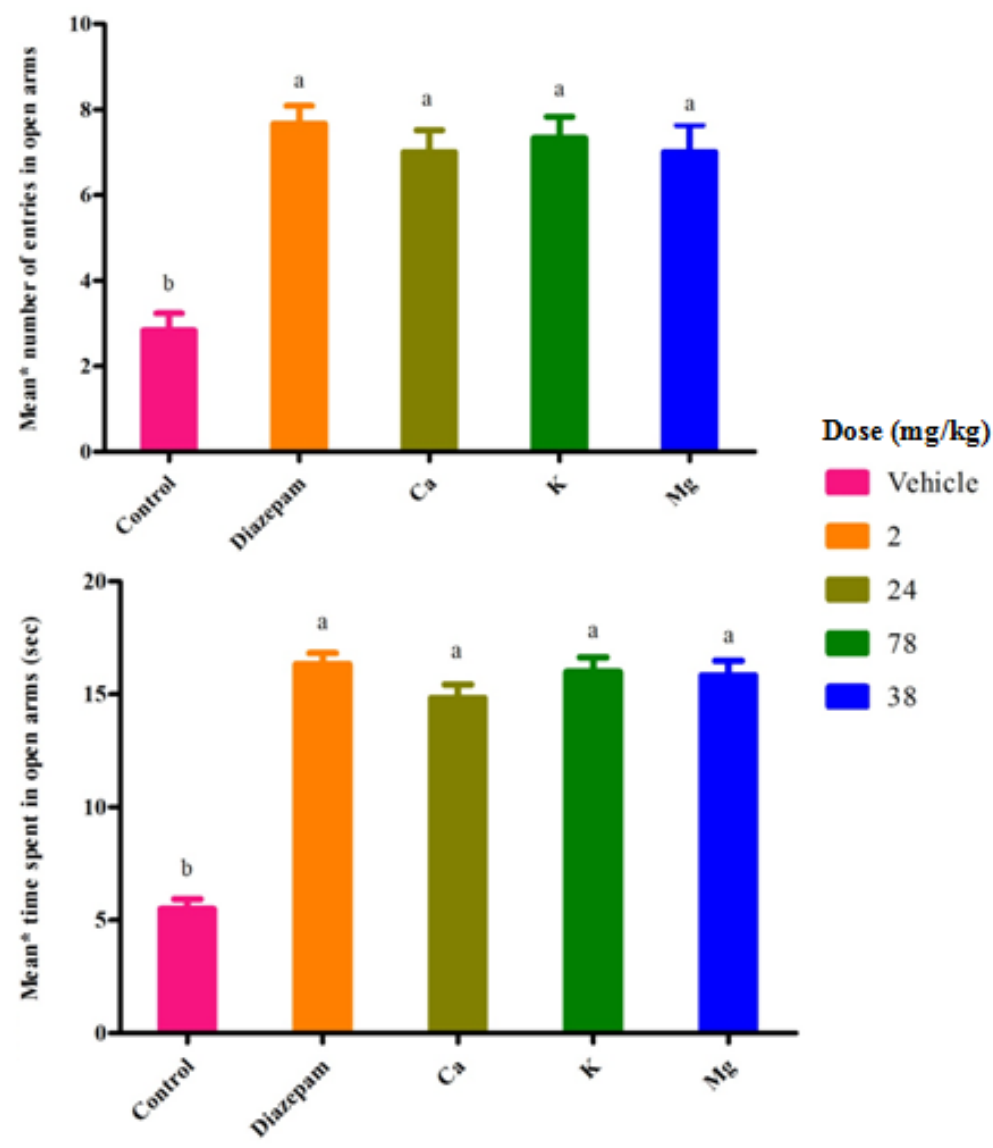

Fig. 5: Antianxiety activity profile of major elements present in the total ash of $H$. sabdariffa calyces, using EPM. The data is expressed as mean $\pm S E M ;{ }^{*} n=6$; ${ }^{\text {ap}}<0.001$ vs diazepam; ${ }^{b} \mathbf{p}<0.001$ vs control; one way ANOVA followed by Tukey's multiple range test

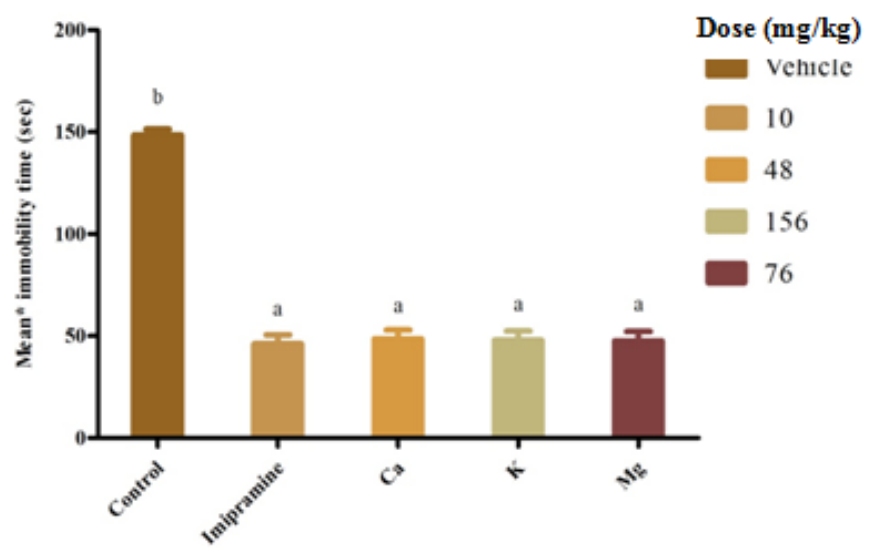

Fig. 6: Antidepressant activity profile of major elements present in the total ash of $H$. sabdariffa calyces, using FST. The data is expressed as mean $\pm S E M ;{ }^{*} n=6$; a $<<0.001 v s$ imipramine; ${ }^{b} p<0.001$ vs control; one way ANOVA followed by Tukey's multiple range test

\section{Elemental analysis of total-ash: ICP-MS technique}

Results of the ICP-MS of total ash of $H$. sabdariffa calyces evinced $\mathrm{K}$, $\mathrm{Mg}$ and $\mathrm{Ca}$ to be the elements with maximum \% concentration. Table 5 shows the percentage concentration of different elements in the total-ash of $H$. sabdariffa calyces.

Antianxiety and antidepressant activity evaluation of salts of major elements present in total ash of $\boldsymbol{H}$. sabdariffa calyces

The salts of major elements exhibited significant antianxiety and antidepressant activity, comparable to the standard anxiolytic and antidepressant agents, respectively. The results of antianxiety and antidepressant activity are depicted in fig. 5 and 6, respectively.

\section{DISCUSSION}

Results of the present study indicate that the total ash of $H$. sabdariffa calyces exhibit significant antianxiety and antidepressant activity at 50 and $100 \mathrm{mg} / \mathrm{kg}$, respectively. The activities were comparable to the standard antianxiety and antidepressant drugs diazepam and imipramine, respectively. However, the major concern associated with powder formulations is ingestion of exact dose and low palatability. Thus, to overcome this problem, the total ash of $H$. 
sabdariffa calyces was formulated into tablets using organic excipients to prevent any elevation or diminution of activity due to inorganic excipients. Prior to the formulation of tablets, various preformulation parameters (angle of repose, bulk density, tapped density, Hausner's ratio and Carr's index) were evaluated for determining the physical properties of active ingredients and excipients. Both the placebo and $H$. sabdariffa total ash tablets conformed to the prescribed norms for the pre-formulation studies. Further, the post formulation parameters were evaluated for the placebo and $H$. sabdariffa total ash tablets to check any defects in the structural integrity of the tablets, and to determine the uniformity of content of the tablets. Both placebo and H. sabdariffa total ash tablets were observed to conform to the laid down standards. The tablets were subjected to antianxiety and antidepressant activity evaluation to compare its activity with that of the total ash, and to observe if there were any changes due to the excipients added in the tablets. Tablet of $H$. sabdariffa total ash exhibited the same level of antianxiety and antidepressant activity as that of the total ash. However, as expected, placebo tablets were devoid of these activities.

Results of the ICP-MS analysis evinced $\mathrm{K}, \mathrm{Mg}$ and Ca to be the major elements in the total ash of $H$. sabdariffa calyces. Numerous studies have indicated that $\mathrm{Mg}, \mathrm{K}$ and $\mathrm{Ca}$ play significant role in the pathogenesis of anxiety and depression and deficiencies of these are known to trigger the symptoms of anxiety or depression $[9,10]$. Thus, to ascertain their role in anxiety and depression, the antianxiety and antidepressant activity of commonly available salts of $\mathrm{Mg}, \mathrm{K}$ and $\mathrm{Ca}$, i.e., $\mathrm{MgSO}_{4}, \mathrm{~K}_{2} \mathrm{SO}_{4}$ and $\mathrm{CaCO}_{3}$ were evaluated. The dose of various elements was selected based on the relative \% concentration of the three major elements ( $\mathrm{Mg}, \mathrm{K}$ and $\mathrm{Ca}$ ) in the total ash of the plant material. The three salts exhibited significant antianxiety and antidepressant activity at their respective doses. Thus, the antianxiety and antidepressant activity of $H$. sabdariffa total ash may be attributed to high concentrations of $\mathrm{Mg}, \mathrm{K}$ and $\mathrm{Ca}$; which are known to have a significant role in affective disorders $[9,10]$.

\section{CONCLUSION}

The present study indicates that total ash of $H$. sabdariffa calyces exhibits significant antianxiety and antidepressant activity in mice on EPM and FST, respectively. Also, the antianxiety and antidepressant activity of the total ash may be attributed to the elements, majorly magnesium, potassium and calcium, which are known to have significant role in pathogenesis of affective disorders. Thus, the results substantiate the role of elements in affective disorders.

\section{ACKNOWLWEDGEMENT}

The authors are thankful to the Council of Scientific and Industrial Research, New Delhi, for financial help to carry out this study.

\section{FUNDING}

Nil

\section{CONTRIBUTION OF AUTHORS}

Findings reported in this manuscript are a part of $\mathrm{PhD}$ project. The project has been conceived by Professor Anupam Sharma and Dr
Ashwani Kumar who are the research supervisors of Ms Gulsheen, SRF. Latter has carried out all the laboratory work.

\section{CONFLICT OF INTERESTS}

None

\section{REFERENCES}

1. Depression and other common mental disorders: global health estimates, World Health Organization; 2020.

2. Nuss P. Anxiety disorders and GABA neurotransmission: a disturbance of modulation. Neuropsychiatr Dis Treat 2015;11:165-75.

3. Fried EI, Epskamp S, Nesse RM, Tuerlinckx F, Borsboom D. What are 'good' depression symptoms? Comparing the centrality of DSM and non-DSM symptoms of depression in a network analysis. J Affect Disord 2016;189:314-20.

4. Zhiguo WU, Yiru FANG. Comorbidity of depressive and anxiety disorders: challenges in diagnosis and assessment. Shanghai Arch Psychiatry 2014;26:227-31.

5. Guzman Gutierrez SL, Chilpa RR, Jaime HB. Medicinal plants for the treatment of nervios, anxiety, and depression in mexican traditional medicine. Rev Bras Farmacogn 2014;24:591-608.

6. Patricia M, Barnes MA, Barbara Bloom MPA. National health statistics reports; no 12. National center for Health Statistics. USA, Hyattsville; 2008.

7. Chaikelis AS. The thiamine content of herbs and medicinal plants. J Am Pharm Assoc 1946;35:343-6.

8. Pal S. The ayurvedic bhasma: the ancient science of nanomedicine. Recent Patents Nanomed 1946;5:12-8.

9. Mlyniec K, Davies CL, de Aguero SIG, Pytka K, Budziszewska B, Nowak G. Essential elements in depression and anxiety. Part 1. Pharmacological Reports 2014;66:534-44.

10. Mlyniec K, Gawel M, Doboszewska U, Starowicz G, Pytka K, Davies CL, et al. Essential elements in depression and anxiety. Pharmacol Reports 2015;67:187-94.

11. Sastri BN. The wealth of India, a dictionary of Indian raw material and Industrial products. Vol. 3. CSIR, New Delhi; 1952.

12. Amos S, Binda L, Chindo BA, Tseja A, Odutola AA, Wambebe C, et al. Neuropharmacological effects of Hibiscus sabdariffa aqueous extract. Pharm Biol 2003;41:325-9.

13. Panesar G, Kumar A, Sharma A. In vivo antianxiety and antidepressant activity of calyx extracts. J Pharm Res 2017;11:962-6

14. Ismail Z, Malaysia KK, Ismail N, Lassa J. Malaysian herbal monograph; 1999.

15. The United States Pharmacopoeia. Vol. 2. United Book Press, Inc; 2014.

16. OECD Guidelines for testing of chemicals: Acute oral toxicityAcute toxic class method. Test no. 423, OECD, Paris; 2001.

17. Pellow S, Chopin P, File SE, Briley M. Validation of open: closed arm entries in an elevated plus-maze as a measure of anxiety in the rat. J Neurosci Methods 1985;14:149-67.

18. Vogel HG, Vogel WH. Drug discovery and evaluation: pharmacological assays. $1^{\text {st }}$ ed. Springer Berlin Heidelberg; 2013.

19. Porsolt RD, Anton G, Blavet N, Jalfre M. Behavioural despair in rats: a new model sensitive to antidepressant treatments. Eur J Pharmacol 1978;47:379-91. 